\title{
Memahami Modal Maya Program Studi
}

\author{
Farham HM Saleh \\ Universitas Islam Indonesia Yogyakarta
}

In the last few years, numbers of university student candidates have been decreasing significantly at most universities in Yogyakarta. This may indicate that performance and competitiveness of these universities have also been decreasing. Such a condition should be responded by university managements, especially head of departments. In order to revitalize their performance and competitiveness, an evaluation should be done, regarding especially two aspects: their customers and virtual capitals. The previous relates to internal, intermediate, and external customers, whilst the latter refer to intellectual, credibility, and social capitals.

Keywords: students, decreased, customer, virtual, capital.

$S^{\text {i }}$ etiap panitia seminar atau pertemuan ilmiah untuk forum diseminasi penelitian atau hasil penelitian ilmiah pasti mengharapkan dapat diikuti oleh sebanyak mungkin peserta atau setidaknya memenuhi target minimal peserta. Salah satu cara yang biasanya digunakan adalah panitia berusaha menampilkan pembicara-pembicara kunci yang "berbobot", mempunyai kredibilitas yang tinggi di bidang keilmuannya, sudah dikenal luas kepakaranya, dan selalu ingin didengar para peneliti tentang pemikirannya. Hal yang sama juga biasanya terjadi pada bisnis pertunjukan. Untuk menarik sebanyak mungkin penonton, panitia berusaha menampilkan tokoh-tokoh ternama, artis atau penyanyi terkenal, atau MC kondang.

Apa yang dilakukan oleh panitia seminar ilmiah maupun panitia bisnis pertunjukan di atas, merupakan suatu usaha untuk mempertinggi "nilai jual" (nilai pasar) dari kegiatan yang dilakukan sehingga calon peserta atau penonton menjadi tertarik. Semakin banyak peserta seminar dan penonton bisnis pertunjukan, selain memperbesar pendapatan yang diperoleh panitia, juga mempertinggi "bobot" dan "kredibilitas" acara yang diadakan.

Kredibiltas, bobot atau nilai jual tidak hanya melekat (dimiliki) ada individu-individu, tetapi juga dapat melekat pada suatu organisasi, suatu perusahaan, atau bahkan suatu Perguruan Tinggi (PT). Bagi calon mahasiswa tertentu seperti dari luar pulau jawa yang ingin studi lanjut di Yogyakarta, kemungkinan terbesar akan memilih Universitas Gajah Mada (UGM) pada PT negerinya dan Universitas Islam Indonesia (UII) pada swastanya. Hal ini karena nama dan kredibilitas kedua PT tersebut telah dikenal luas di hampir seluruh wilayah nusantara.

Perguruan tinggi umumnya mempunyai beberapa fakultas dan setiap fakultas membawahi satu atau lebih jurusan, yang masing-masing jurusan membawahi satu atau lebih program studi. Nama besar atau kredibilitas suatu PT dapat bersumber dari perjalanan prestasi PT itu sendiri, fakultas, program studi, atau bahkan lembaga kemahasiswaan. UII menjadi lebih dikenal secara nasional karena beberapa dosennya menjabat pada posisi-posisi penting seperti Ketua Komisi Yudisial, Hakim Agung, mantan Menteri Pertahanan, Bupati, 
Memahami Modal Maya Program Studi; Farham HM Saleh

Walikota, atau lebih dikenal karena dinamika lembaga kemahasiswaannya. Istilah kredibilitas, berbobot, dan nilai jual, oleh beberapa pakar didefinsikan sebagai modal maya (virtual capital).

Beberapa tahun terakhir, terjadi penurunan yang cukup signifikan jumlah calon mahasiswa di hampir semua PT di

\section{Modal Maya}

Business Week edisi 12 Juli 1999 dan sumber lain (Tjakraatmadja, 2002) mengemukakan perbandingan antara nilai pasar dan nilai aset beberapa perusahaan terkenal pada tahun 1999 seperti ditunjukkan Tabel 1.

Tabel 1: Nilai Pasar dan Nilai Aset Tahun 1999 beberapa Perusahaan Terkenal

\begin{tabular}{|l|l|c|c|}
\hline No. & Perusahaan & $\begin{array}{c}\text { Nilai Pasar tahun } \\
1999\end{array}$ & $\begin{array}{c}\text { Nilai Aset tahun } \\
1999\end{array}$ \\
\hline 1. & Microsoft & $407,22(\mathrm{M} \$)$ & 22,367 (M \$) \\
2. & General Electric (GE) & $333,05(\mathrm{M} \$)$ & $355,940(\mathrm{M}$ \$) \\
3. & Yahoo & $29,45(\mathrm{M} \$)$ & - \\
4. & PT. Telkom Tbk & $4,48(\mathrm{M} \$)$ & - \\
\hline
\end{tabular}

Sumber: Tjakraatmadja (2002, hal. 7)

Yogyakarta. Penurunan jumlah calon mahasiswa tersebut disikapi sangat beragam oleh pimpinan PT, baik di tingkat rektorat, dekanat maupun di tingkat pengelola prodi. Secara umum mereka berpendapat bahwa penurunan jumlah calon mahasiswa tersebut merupakan hal yang wajar sebagai dampak dari otonomi daerah, di beberapa propinsi telah berdiri perguruan tinggi. Sangat sedikit pengelola PT yang menyadari bahwa penurunan jumlah calon mahasiswa tersebut merupakan indikator bahwa performansi, kredibilitas atau nilai jual mereka menurun. Makalah ini mencoba mengevaluasi siapa sesungguhnya konsumen prodi dan mengemukakan beberapa modal berupa modal maya, yang dapat digunakan oleh pengelola PT khususnya pengelola program studi untuk mempertinggi nilai jualnya.
Tabel 1 menunjukkan bahwa Microsoft memiliki nilai pasar lebih dari 18 kali nilai asetnya, dan bahkan lebih besar dari nilai pasar GE yang memiliki nilai aset 16 kali Microsoft. Hal yang sama terjadi pada Yahoo, yang ternyata memiliki nilai pasar lebih dari enam kali PT. Telkom Tbk. Sementara itu nilai aset GE lebih besar dari nilai pasarnya. Fenomena apa sesungguhnya yang terjadi, di satu sisi ada perusahaan terkenal yang nilai pasarnya jauh lebih besar dari nilai asetnya, sedangkan di sisi lain ada perusahaan terkenal yang nilai asetnya justru lebih besar dari nilai pasarnya.

Jika aset perusahaan-perusahaan di atas merupakan aset fisik, maka selisih antara nilai pasar dengan nilai aset perusahaan tersebut dapat menggambarkan besarnya modal maya, yang oleh beberapa pakar diistilahkan dengan intellectual capi- 
tal (Roos, 1996; Brooking dan Mota, 1996), human capital (Stewart, 1997), semuanya dalam Tjakraatmadja (2002), dan virtual capital (Hartanto, 1999). Dalam Tjakraatmadja (2002), Roos (1996) mendefinisikan intellectual capital sebagai nodal yang tidak terlihat secara nyata, namun memberikan nilai tambah yang sangat besar pada stakeholders, sedangkan Brooking dan Mota (1996) mendefinsikan sebagai intangible asset, yang merupakan gabungan dari faktor manusia, proses dan pelanggan, yang memberikan keunggulan kompetitif bagi perusahaan. Sementara itu Stewart (1997) mendefinisikan intellectual capital (dalam menjelaskan human capital) sebagai talenta, kemampuan, keterampilan, dan gagasan pekerja. Selanjutnya Hartanto (1999) mendefinisikan virtual capital (modal maya) sebagai modal yang terbentuk dari modal intelektual, modal sosial dan modal lunak (modal krediblitas). Tjakraatmadja dan Safitri (2000) mengemukakan bahwa modal virtual atau modal insani terdiri dari modal intelektual, modal kredibilitas dan modal sosial, yang berasal dari kompetensi yang 'embedded' pada diri setiap manusia.

Dengan pengertian tersebut di atas, berarti ada perusahaan yang mempunyai modal maya positif seperti Microsoft dan ada perusahaan yang bermodal maya negatif seperti GE. Kedua kondisi ini merupakan hal yang lumrah dalam kehidupan termasuk dalam kehidupan akademik seperti ada professor yang "nilai pasar"nya tidak lebih dari kontribusinya pada akreditasi suatu program studi tetapi banyak juga yang "nilai pasar"nya jauh lebih besar dari ke-profesorannya.

\section{Program Studi}

Secara umum Program Studi (prodi) merupakan suatu unit di PT, yang merepresentasikan satu bidang ilmu tertentu, yang secara organisatoris berada di bawah jurusan atau fakultas. Karena merepresentasikan suatu bidang ilmu tertentu, maka prodi mengemban tugas sebagai ujung tombak dalam mengelola dan mengembangkan bidang akademik keilmuan prodi tersebut. Oleh karena tugas tersebut, setiap prodi mencakup empat komponen atau unsur yang saling berinteraksi yaitu unsur pimpinan atau pengelola prodi, dosen, mahasiswa dan unit pendukung (administrasi dan laboratorium).

Pimpinan prodi merupakan pengarah dan pengendali utama perjalanan prodi, ibarat dirijen pada pementasan orkestra, sebagai nakhoda pada kapal, dan sebagai kapten tim pada sepakbola. Dengan posisi tersebut, pimpinan prodi antara lain bertugas merencanakan dan melaksanakan pengembangan akademik keilmuan, mengontrol semua kegiatan yang berada di bawah koordinasi dan tanggung jawabnya.

Sesuai dengan tridharma perguruan tinggi, tugas dosen adalah melaksanakan pendidikan dan pengajaran, penelitian dan publikasi ilmiah, dan pengabdian pada masyarakat. Mahasiswa melaksanakan kegiatan akademik dan aministratif yang menjadi kegiatan rutin setiap prodi yaitu mengikuti perkuliahan, melaksanakan praktikum, mengerjakan tugas akhir, dan kegiatan aministrasi seperti registrasi. Sedangkan unit pendukung bertugas melaksanakan kegiatan administratif dan menyelenggarakan praktikum di laboratorium. Secara skematis, hubungan interaksi keempat unsur dalam suatu prodi ditunjukkan Gambar 1. 
Memahami Modal Maya Program Studi; Farham HM Saleh

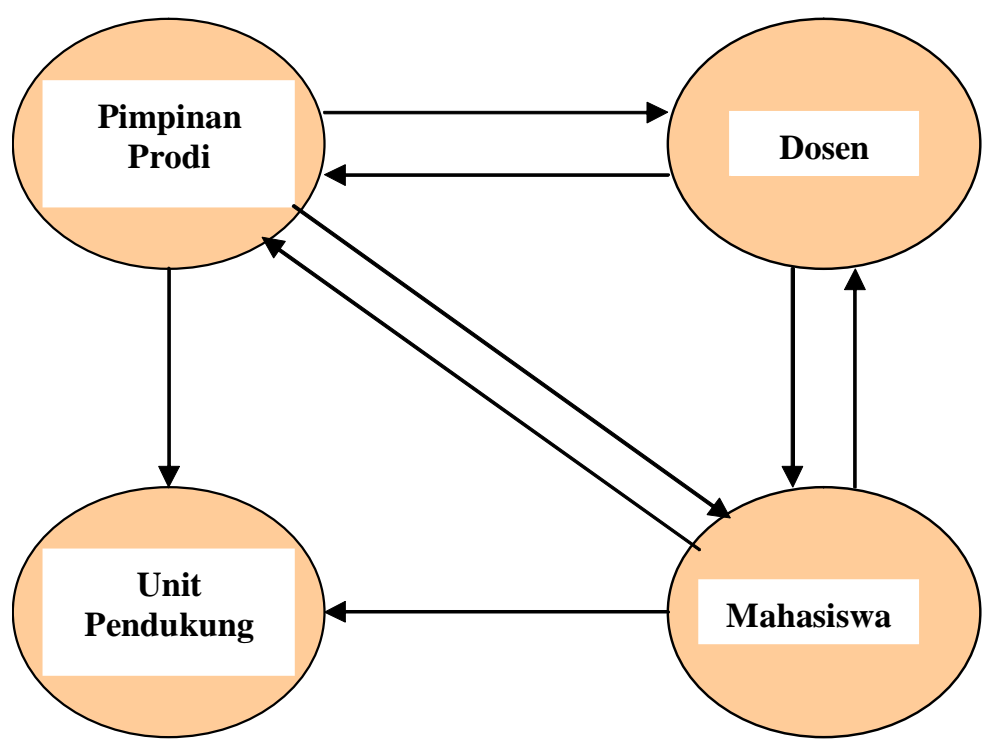

Gambar 1: Interaksi di antara unsur-unsur Prodi

Gambar 1 memperlihatkan hubungan interaksi di antara keempat unsur prodi. Secara singkat hubungan interaksi tersebut dijelaskan di bawah ini.

\section{Interaksi Pimpinan Prodi dengan dosen}

Pimpinan prodi bersama dewan dosen antara lain mendiskusikan rencana pengembangan akademik prodi, menyepakati mata kuliah yang diampu setiap dosen sesuai dengan kelompok kompetensi masing-masing dosen, menyepakati matrikulasi studi lanjut dosen, serta koordinasi pelaksanaan perkuliahan dan kegiatan ilmiah seperti seminar, symposium dan workshop, baik yang dilaksanakan secara internal maupun eksternal.

\section{Interaksi Pimpinan Prodi dengan Mahasiswa}

Pimpinan prodi mengkoordinasikan dengan unit pendukung dan dosen-dosen untuk melaksanakan kegiatan dan administrasi akademik bagi mahasiswa. Jika dalam pelaksanaan kegiatan akademik dan administratif tersebut, mahasiswa berinteraksi dengan unit pendukung dan dosen, terdapat hal-hal yang kurang sesuai atau menyimpang, misalnya dosen tidak aktif mengajar atau sikap karyawan unit pendukung kurang tepat, maka hal-hal tersebut menjadi hak mahasiswa untuk dikeluhkan pada pimpinan prodi. Hal tersebut di atas merupakan salah satu bentuk interaksi antara mahasiswa baik secara individu maupun melalui lembaga kemahasiswaan dengan pimpinan prodi. 
UNISIA, Vol. XXX No. 66 Desember 2007

\section{Interaksi Dosen dengan Mahasiswa}

Interaksi antara dosen dengan mahasiswa terjadi antara lain pada perkuliahan, perwalian, diskusi, peneltian bersama, pengabdian masyarakat, kuliah kerja nyata, dan pembimbingan tugas-tugas akhir. Namun juga terdapat interaksi yang bersifat pribadi non formal seperti kesamaan hobi, aktivitas keagamaan dan sosial kemasyarakatan.

\section{Modal Maya Prodi}

Telah dikemukakan sebelumnya bahwa modal maya adalah selisih dari nilai pasar dengan nilai aset fisik suatu perusahaan atau organisasi. Nilai pasar suatu perusahaan secara umum ditentukan oleh konsumen yang membeli produk perusahaan tersebut, sedangkan secara spesifik di pasar modal nilai pasar digambarkan oleh harga saham perusahaan tersebut yang bersedia dibeli oleh konsumen. Artinya konsumenlah yang menentukan nilai pasar suatu perusahaan.

Gaspersz (1997) mengemukakan bahwa terdapat tiga macam konsumen (pelanggan) yaitu konsumen internal (internal costumer), konsumen antara (intermediate customer), dan konsumen eksternal (external customer). Konsumen internal suatu perusahaan adalah karyawan atau orang yang berada di dalam perusahaan, yang memiliki pengaruh pada performansi atau kinerja perusahaan. Dalam hal prodi, pimpinan prodi harus memandang dosen, karyawan dan mahasiswa sebagai pelanggan yang harus dipuaskan, sehingga dalam setiap aktivitas yang berhubungan dengan dosen, karyawan dan mahasiswa, pimpinan prodi harus selalu mengingat bahwa mereka adalah pelanggan.
Konsumen antara adalah mereka yang bertindak atau berperan sebagai perantara, bukan sebagai pemakai akhir (end user) produk perusahaan. Sedangkan pelanggan eksternal adalah orang-orang atau organisasi yang membeli produk (jasa) dari perusahaan untuk digunakan sendiri (end user). Artinya pelanggan eksternal merupakan pelanggan nyata dari perusahaan. Dalam hal prodi, pelanggan antara misalnya perusahaan penyalur tenaga terdidik, sedangkan pelanggan eksternal adalah calon mahasiswa, industri dan masyarakat umum.

Dengan menggunakan pengertian konsumen dari Gaspersz (1997) tersebut di atas, maka konsumen prodi adalah dosen, karyawan, dan mahasiswa, yang dapat dipandang sebagai konsumen internal dan konsumen antara, sedangkan calon mahasiswa (beserta keluarganya) dan industri serta masyarakat sebagai end user dari sarjana yang dihasilkan prodi sebagai konsumen eksternal. Dosen, karyawan, dan mahasiswa dapat dipandang sebagai konsumen internal karena mereka merupakan elemen yang harus dipuaskan oleh pimpinan prodi, sedangkan sebagai pelanggan antara karena mereka dapat berfungsi baik secara langsung maupun tidak lansung sebagai penyampai informasi tentang performansi prodi kepada pelanggan eksternal.

Pada bagian awal makalah ini telah dikemukakan bahwa modal maya terdiri dari modal intelektual, modal kredibilitas, dan modal sosial. Ketiga komponen modal maya tersebut, dapat dimiliki oleh setiap individu atau setiap organisasi termasuk prodi. Di bawah ini akan dikemukakan hal-hal yang dapat menjadi modal maya prodi, yang secara umum dinilai oleh konsumen antara lain kompetensi prodi, figur pimpinan prodi, kompetensi dosen, dan interaksi antara pimpinan prodi, dosen dan mahasiswa. 
Memahami Modal Maya Program Studi; Farham HM Saleh

\section{Kompetensi Prodi}

Setiap prodi pasti mempunyai kompetensi, yang secara umum diartikan sebagai pilihan keahlian atau profesi dari sarjana yang dihasilkan oleh prodi tersebut. Kompetensi prodi murni berasal dari bidang ilmu prodi atau juga dari "ramuan" dengan bidang ilmu pendukung. Konsumen dapat menilai kompetensi prodi dari beberapa indikator antara lain keterserapan sarjana yang dihasilkan oleh dunia kerja, keberhasilan alumninya di masyarakat dan kompetensi dosen.

Keterserapan alumni oleh dunia kerja umumnya menjadi indikator utama penilaian konsumen terhadap kompetensi prodi, karena secara umum tujuan menjadi sarjana adalah mempertinggi kemampuan mendapatkan pekerjaan dengan gaji yang memadai. Jika alumni suatu prodi selalu dengan cepat terserap oleh lapangan pekerjaan dengan gaji yan memadai, maka dapat dipastikan kredibilitas prodi tersebut akan dinilai sangat tinggi oleh konsumen, begitu juga sebaliknya. Keberhasilan alumni suatu prodi, terutama pada bidang kompetensinya akan dinilai oleh konsumen bahwa prodi tersebut berhasil melaksanakan proses pendidikan dengan baik atau mempunyai performansi yang meyakinkan. Sedangkan kompetensi dosen, berkaitan dengan pengetahuan konsumen tentang kepakaran (kompetensi) seorang dosen, baik tingkat pendidikan, kualifikasi akademik, maupun karya-karya ilmiahnya.

Gede Raka (2007) mengemukakan bahwa salah satu faktor untuk mempunyai daya tahan dan daya tumbuh dalam dunia yang kompetitif adalah dengan memiliki dan mengembangkan kompetensi. Oleh karena itu harus disadari oleh pengelola prodi bahwa kompetensi prodi merupakan modal maya utama yang dapat digunakan untuk mempertahankan bahkan mengembangkan eksistensi prodi.

\section{Figur dan Kemampuan Manajerial Pimpinan Prodi}

Seperti dikemukakan pada bagian awal makalah ini, nama besar atau kredibilitas seseorang dapat mempertinggi "nilai jual" suatu event. Hal yang sama juga dapat terjadi pada pimpinan prodi. Pimpinan prodi yang telah dikenal luas namanya terutama dalam hal kepakaran, kemampuan leaderhip-nya atau kemampuan networkingnya, akan mempertinggi penilaian konsumen terhadap performansi prodi tersebut. Pimpinan prodi yang dikenal luas kepakarannya dan kemampuan leadershipnya, akan dapat dipercaya oleh masyarakat kemampuannya mengelola prodi untuk menghasilkan sarjana yang berkompeten. Kemampuan mengelola merupakan komponen utama yang mempengaruhi kesuksesan suatu perusahaan atau organisasi [Gaspersz, 1997; Yuwono, Sukarno, dan Ikhsan, 2003]. Kepercayaan masyarakat tersebut, dapat menjadi modal maya prodi, berupa modal kredibilitas. Sedangkan kemampuan networking pimpinan prodi dapat menjadi modal maya prodi berupa modal social, minimal di lingkungan relasionalnya.

Indikator minimal tingkat performansi pengelola prodi yang secara langsung dapat dinilai oleh konsumen adalah tingkat pendidikan dan kualifikasi akademik. Seorang pengelola prodi yang bergelar doktor, dapat dipastikan akan dinilai lebih kredibel oleh konsumen dalam memimpin prodi dibandingkan dengan yang bergelar magister. Seorang guru besar akan dinilai oleh konsumen lebih kredibel dibandingkan dengan yang lektor kepala. 
UNISIA, Vol. XXX No. 66 Desember 2007

\section{Kompetensi Dosen}

Salah satu indikator tingkat performansi prodi adalah kompetensi dosen. Prodi yang memiliki dosen-dosen yang dikenal luas oleh masyarakat karena kompetensi (kepakaran)-nya, baik lokal maupun nasional, cenderung dinilai sebagai prodi yang berhasil oleh konsumen. Oleh karena itu konsep pemikiran seorang dosen, hasilhasil penelitiannya terutama penelitian implementatif yang sangat bermanfaat bagi industri dan masyarakat, harus dipublikasikan secara luas, baik di jurnal ilmiah, forum ilmiah maupun di media massa agar nilai manfaatnya dapat dirasakan oleh masyarakat pengguna. Kompetensi dosen juga dapat diketahui oleh masyarakat luas karena keterlibatannya dalam struktural pemerintahan karena kepakarannya. Pimpinan prodi harus benar-benar faham dan mampu mengelola dengan tepat kompetensi dari setiap dosen sehingga mampu menjadi modal maya prodi.

\section{Interaksi antara pimpinan prodi dengan dosen}

Pada sub bagian sebelumnya telah dikemukakan bentuk interaksi antara pimpinan prodi dengan para dosen. Bentukbentuk interaksi tersebut jika berjalan harmonis, akan berdampak positif pada kinerja keduanya yaitu terbangunnya kemampuan pimpinan prodi untuk melaksanakan fungsinya dengan baik dan terbangunnya kompetensi dosen karena kegiatan tridharmanya dilakukan dalam suasana yang kondusif. Keharmonisan hubungan keduanya dapat terbangun jika telah terbangun rasa saling percaya dan komitmen [Bounds, et.al., 1994; Goetch dan Davis, 1997; Hartanto, 2000; dan Pramudya, 2001] atas tugas dan fungsi masing-masing dan untuk membangun kompetensi prodi.
Rasa saling percaya merupakan salah satu media yang subur untuk bertumbuh kembangnya sinergi kemampuan (kompetensi), baik kemampuan intelektual, komitmen dan kemampuan sosial di antara individu-individu menjadi kompetensi kelompok atau organisasi, bahkan juga sinergi antara individu dengan organisasi untuk menghasilkan modal maya organisasi (Tjakraatmadja, 2002). Hal ini harus disadari oleh pimpinan prodi maupun dosen sehingga terjadi sinergi yang harmonis antara keduanya, berlandaskan rasa saling percaya akan hak dan kewajiban masingmasing.

Secara langsung tingkat keharmonisan hubungan antara pimpinan prodi dengan para dosen juga akan dinilai oleh konsumen, terutama konsumen internal dan konsumen antara. Hal ini berarti dapat mempengaruhi tinggi rendahnya modal maya prodi.

\section{Interaksi antara pimpinan prodi dengan mahasiswa}

Antara pimpinan prodi dengan mahasiswa terdapat kesamaan tujuan yaitu menghasilkan (menjadi) sarjana yang berkompeten, yang cepat terserap oleh lapangan kerja. Kesamaan tujuan ini menjadi dasar interaksi dan sinergi di antara keduanya Namun demikian, yang harus disadari oleh pimpinan prodi adalah mahasiswa dapat merupakan konsumen internal, antara dan eksternal, yang setelah menjadi alumni dapat menjadi konsumen potensial bagi prodi. Oleh karena itu, interaksi dan sinergi selama mereka berstatus sebagai mahasiswa harus dikelola dalam rangka tujuan jangka panjang prodi. Bentuk-bentuk interaksi yang non formal seperti memperlakukan sebagai anak, sebagai saudara, sebagai mitra dialog pengembangan keilmuan dan kompetensi, 
Memahami Modal Maya Program Studi; Farham HM Saleh

akan membuat jaringan hubungan prodi dengan alumni menjadi berkelanjutan.

\section{Interaksi antara dosen dengan mahasiswa}

Interaksi antara dosen dengan mahasiswa seharusnya berjalan harmonis karena keduanya saling membutuhkan. Dosen membutuhkan mahasiswa untuk memperbesar nilai manfaat dari penyebaran dan implementasi keilmuannya, sedangkan mahasiswa membutuhkan dosen sebagai pembuka dan pengarah untuk menjadi sarjana yang berkompeten. Oleh karena itu bentuk interaksi yang sebaiknya dibangun oleh dosen adalah bentuk kemitraan.

\section{Penutup}

Penurunan jumlah calon mahasiswa di hampir semua perguruan tinggi di Daerah Istimewa Yogyakarta (DIY) dalam beberapa tahun terakhir, seharusnya membuat pengelola perguruan tinggi di DIY, khususnya pimpinan prodi sadar bahwa daya saing atau performansi mereka menurun di mata calon mahasiswa atau konsumen umumnya. Beberapa hal yang dapat menjadi potensi untuk meningkatkan kembali daya saing dan performansi mereka di antaranya:

1. Terdapat tiga macam konsumen prodi yaitu konsumen internal, konsumen antara dan konsumen eksternal. Konsumen internal adalah karyawan, dosen dan mahasiswa. Konsumen antara adalah perusahaan penyalur tenaga sarjana, sedangkan konsumen eksternal adalah calon mahasiswa, industri dan masyarakat. Pemahaman dan perlakuan yang tepat terhadap ketiga macam konsumen ini akan dapat meningkatkan kembali penilaian konsumen terhadap performansi prodi.

2. Untuk mempertinggi penilaian konsumen terhadap performansi prodi, terdapat tiga modal dasar yang dimiliki setiap prodi yaitu modal intelektual, modal kredibilitas dan modal sosial yang oleh beberapa pakar disebut sebagai modal maya (virtual capital). Jika ketiga modal ini dikelola dengan baik dan disinergikan, diyakini akan dapat meningkatkan penilaian konsumen terhadap performansi prodi.

3. Modal maya prodi dapat terkandung pada semua elemen yang menjadi komponen prodi dan pada interaksi di antara elemen-elemen tersebut. Elemen-elemen tersebut di antaranya pimpinan prodi, dosen, mahasiswa, dan unit pendukung seperti laboratorium dan administratif.

4. Pengelolaan yang benar dan terarah dari elemen-elemen dan interaksi antara elemen-elemen tersebut akan dapat membangkitkan modal maya prodi.

Namun demikian kesuksesan membangun modal maya prodi akan sangat ditentukan oleh kemampuan pimpinan prodi bertindak sebagai manajer sekaligus leader, dalam membangkitkan komitmen dan kesadaran akan hak dan kewajiban masingmasing elemen pembentuk prodi.

\section{Daftar Pustaka}

Bounds, G., Yorks, L., Adams, M., dan Ranney, G., 1994, Total Quaity Management: Toward the Emerging Paradigm, McGraw-Hill International Editions, Singapore

Gaspersz, V, 1997, Manajemen Kualitas Dalam Industri Jasa, PT Gramedia Pustaka Utama, Jakarta

Goetsch, D.L. dan Davis, S.B., 1997, Introducion to Total Qualty, Quality 
UNISIA, Vol. XXX No. 66 Desember 2007

Management for Production, Processing, and Services, Second Edition, Prentice-Hall International, Inc., New Jarsey, USA

Hartanto, F.M., 1999, Peran Modal Virtual dalam Bisnis Logistik dan Distribusi, Jurnal ISTMI Teknik Industri dan Manajemen Industri, volume 3 nomor 1 tahun 199, hal. 6-16

Hartanto, F.M., 2000, Manusia Karya yang Besumberdaya di dalam Sistem Usaha: Paradigma Tenaga Kerja di abad ke-21, Jurnal Bisnis dan Ekonomi Kinerja, Volume 4, No. 1, Th 2000, hal. 19-39

Pramudya, E.E. 2001, Pengaruh Rasa Saling Percaya untuk Meningkatkan Kualitas Lingkungan Belajar untuk Merealisasikan Proses Transformasi Potensi Etikal Individu menjadi Modal Kredibilitas Organisasi, Thesis-S2 Industrial Management Institut Teknologi Bandung (diambil melalui: www.digilib.itb.ac.id/gdl, tanggal 11 Juni 2007)
Raka, I.G, 2007, Etika, Masalah Hidup atau Mati, Studium Generale dengan Thema: "Membangun Mental Engineer Muda yang Jujur, Profesional, dan Kontributif Bagi Bangsa Indonesia, HM Sipil ITB, 6 Maret 2007, Bandung

Tjakraatmadja, J.H, 2002, Manajemen Transformasi Pengetahuan dalam Tim dan Organisasi Belajar, Disertasi, Institut Teknologi Bandung

Tjakraatmadja, J.H. dan Safitri, 2000, Pengaruh Pemberdaya Organisasi pada Proses Transformasi Disiplin Belajar menjadi Tim Belajar Yang Efektif, Jurnal Teknik dan Manajemen Industri, Volume 20 Nomor 3 Desember 2000, hal 11-20

Yuwono, S., Sukarno, E., dan Ikhsan, M., 2003, Petunjuk Praktis Penyusunan Balanced Scorecard, Menuju Organisasi Berfokus pada Strategi, Cetakan Kedua, PT. Gramedia Pustaka Utama, Jakarta 